\title{
Investigation of Corruption for Government Goods and Services Procurement: A Police Perspective
}

\author{
Muhammad Yusuf*, Syamsul Bachri, Slamet Sampurno, Muhadar \\ Graduate School, Hasanuddin University, South Sulawesi - Indonesia \\ * Corresponding author
}

\begin{abstract}
The development of corrupt behavior has disrupted the States' economy, hampered national development in various fields, and damaged the life in society, nation and State. These matters have the greatest potential for endangering the existence of the States' functioning so it can cause in the failure of ideals national goals. This research was conducted in the jurisdiction of West Papua Police - Indonesia. The type of research is oriented to socio-legal research. The results shows that the implementation of Police Investigation' authority in corruption investigation in the field of Government's Goods and Services Procurement in West Papua Provincial, there are two elements between prosecutor and Police investigators which implies not optimal the principle of checks and balances between the prosecutor investigator and Sub-Directorate III of West Papua Police.The implementation of corruption investigation by West Papua Police investigator and prosecutor or High Court of Papua is supported by coordination and integration to be a responsive law enforcement for corruption.
\end{abstract}

Keywords: Corruption, Goods and Services, Police

\section{INTRODUCTION}

The corruption is still a major issue in this country. It has occurred in all aspects of community life and business sector. In everyday, almost the mass media, both nationally and locally, reports issues or problems about corruption. As a result of increasing corruption, the public consciously or unconsciously becomes the main victim, while the State has to bear substantial material and non-material losses. In $2014{ }^{1}$ the government is targeting a number of measurable improvements, likes the government targeting 5.0 for Indonesia's Corruption Perception Index, as well as the settlement of 100 percent recommendation of the review result of United Nation Convention Against Corruption (UNCAC) as a measure of corruption eradication. In 2016, ${ }^{2}$ the government focused on the governments' work plan by taking the theme of "accelerating infrastructure development to strengthen the foundation of quality development" as stated in Presidential Regulation No. 60 of 2015 on Governments' Work Plan 2016. To realize the theme has been scheduled 3 (three) dimensions of development that is the dimension of human development, the dimension of superior sector development and the dimension of equity and territorial development. On the other hand, efforts to realize the themes are still facing challenges include the rise of corruption practices that have developed with massive and spread to all aspects of community life. ${ }^{3}$ Starting from the practice of small corruption like an illegal collection with the reason as administrative costs or "money thanks" until large corruption. Furthermore, efforts to eradicate corruption in Indonesia are also faced with several challenges such as the development of increasingly complex modus operandi of corruption.

One of the most vulnerable public sectors ${ }^{4}$ of corruption is the process of "Government's Goods and Services Procurement" which is often considered to be a wet sphere for corrupt practices. The procurement of Government's Goods and Services financed by National/Regional Budgets which can be carried out either by self-management or goods/services procurement and contracting out services in which the specific planning is determined by the commitment maker (the user of goods/services) and its implementation process is supervised by the commitment maker. The potential for corruption in an area in the project of goods or services procurement is quite possible. In essence, ${ }^{5}$ the corruption crime has been carried out by law enforcement officers

\footnotetext{
${ }^{1}$ Komisi Pemberantasan Korupsi, Pedoman Pengendalian Gratifikasi, (Jakarta: KPK, 2015), page. 9.

${ }^{2}$ Ibid.

3 Roy, Subir Kumar. (2016). "Consumer Justice: A Symbol of Economic Prosperity and Social Progressiveness." Hasanuddin Law Review,2(2): 170-181. DOI: http://dx.doi.org/10.20956/halrev.v1n2.302

${ }^{4}$ Ermansyah Djaja, Memberantas Korupsi Bersama KPK, Komisi Pemberantasan Korupsi, (Jakarta:Sinar Grafika, 2009), page. 28.

${ }^{5}$ Ibid. 
such as Police, Attorney and Corruption Eradication Commission. Related to the existence of Police as one institution given the duties, functions and authority to conduct investigations on corruption case in Indonesia, by itself demanded the investigators of Police to more improve performance and professionalism in investigation, so that the results achieved from the investigation become an integral part of the action aimed at eradicating the corruption in Indonesia. The more increasingly corruption in Indonesia, demanding the role of investigators and co-investigators of Police actively to try to increase knowledge, abilities and skills in the field of investigation in order to be able to investigate all corruption cases indiscriminate and selective as a form of the involvement of Police to eradicate corruption that has infiltrated all this nation and State' life. The research focused to analyze the role of Police Investigator of West Papua Police on law enforcement of corruption both law enforcement in action and prevention.

\section{METHOD OF RESEARCH}

This research was conducted in the jurisdiction of West Papua Police - Indonesia. This site is expected to provide an overview regarding the role of Police as the investigator of corruption in West Papua. The type of research is oriented to socio-legal research, where its application and implementation relate various paradigms of social and police sciences as well as existing legal theories by using a functional structural macro approach.

\section{RESULT AND DISCUSSION}

\section{General Review of Police in West Papua Province}

Corruption investigator that authorized to conduct an investigation is under the control of the Special Criminal Investigation Director of the West Papua Police led by a member of the Police with a rank of Chief Commissioner and has a Sub Directorate of Corruption with a rank of AKBP with 1 personnel from the West Papua Police and a total of 43 persons with the distribution of investigative personnel force.

The investigation of alleged criminal acts of corruption are internally the Police is coordinated directly by the Director of Special Criminal Investigation of West Papua, while in operating technical the implementation of corruption investigation is realized in the form of Corruption Unit under the control of Sub Directorate with a rank of AKBP, while the Corruption Unit at Police Resort are coordinated by Kasat Reskrim with a rank of AKK.As reports received through complaints for corruption in last five years (2012-2017), there were 38 cases and P21 complete 21 cases $(63.64 \%)$ and the resting is 10 cases $(30.30 \%)$. The alleged corruption as reported by the public to the investigators of West Papua during the last five years totaled 33 cases with an estimated State's financial loss of Rp. 39.424.590.479. While,success saved is Rp. 27.916.327.500 or 70.81\%.

For more details on reports and public complaints regarding to the corruption in the past five years, can concerned about the empirical figures in Table 1.

Table 1. Corruption crime that handled by Corruption Unit Investigator of West Papua Police

\begin{tabular}{|c|c|c|c|}
\hline Years & Entry Report & Report Complete (P21) & Percentage \% \\
\hline 2012 & 4 & 4 & 19,05 \\
2013 & 6 & 6 & 28,57 \\
2014 & 8 & 3 & 14,29 \\
2015 & 9 & 6 & 28,57 \\
2016 & 5 & 2 & 09,52 \\
2017 & 6 & 0 & 0 \\
\hline & 38 & 21 & 100,00 \\
\hline
\end{tabular}

Source: Papua Police Data and West-Papua, 2017

As Table 1 above, from total numbers of corruption in West Papua Police as many 38 cases and successfully completed in file P-21 accepted by the attorney as the public prosecutor as much 21 cases and 17 cases are still in the process of investigation.

\section{Analysis of Legal Substance of Corruption Eradication}

The legal substance of corruption investigation includes all legal principles, norms and rules, whether in written or unwritten form is a reference for investigators to carry out their duties, functions and authority to investigate any person allegedly involved in corruption. ${ }^{6}$ The legal principles, norms and rules as contained in Act No. 8 of 1981, Act No. 8 of 1981, Act No. 31 of 1999 in conjunction with Act No. 20 of 2001 as well as Act No. 2 of 2002, is just one sub in legal substance or not as a whole. It is important to distinguish legal norms against other social norms (norms of customary, discipline, moral, religious, etc.) so that the purpose of investigation can be realized as it should be.If traced more systematic and deep, then the success of legal substance cannot be separated from the support of legal structure and culture. Here, the legal structure includes

\footnotetext{
${ }^{6}$ Indriyanto Seno Adji, Arah Sistem Peradilan Pidana, (Jakarta: Prof. Oemar Seno Adji, S.H \& Co. Law firm, 2001), page. 46
} 
the entire law enforcement agencies and their apparatuses, along with all facilities and infrastructure and facilities available in the context of the implementation of corruption investigation in Indonesia. Similarly, the legal culture is oriented to the habits, opinions and ways of thinking and how to act Corruption Unit Investigator of West Papua Police in order to eradicate Corruption. The successful of corruption investigation as conducted by the Corruption Unit Investigators of West Papua Police is more influenced by the availability of legal that provides clarity on the role or function of the police investigation authority to conduct investigations on corruption cases. As described above, the implementation of corruption investigation in the decade of HIR to be a role, function, authority of the attorney, but through the Criminal Procedure Code (KUHAP) where the police investigators are normatively appointed as sole investigators of public crimes, the success of the Police to carry out this investigative duty is considered to have more role if given also role, function and investigation to corruption case as intended by Act No. 31 of 1999 jo Act No. 20 of 2001.If carefully reviewed the conception of Act No. 31 of 1999 jo Act No. 20 of 2001, it is clear that there are 2 (two) institutions authorized to carry out investigations on corruption crime, namely the Attorney and Police. The attorney beside as investigator and public prosecutor, it is also appointed as the coordinator authorized to coordinate the implementation of corruption crime investigation, including the investigations by investigators/co-investigators of the Police Corruption Unit.

The development of legal substance of corruption crime investigation in Indonesia, following the establishment of Corruption Eradication Commission according to Act No. 30 of 2002, the Corruption Eradication Commission is authorized to carry out investigation on corruption and is also authorized to coordinate the implementation of investigations either handled by investigators/co-investigators of the Police Corruption Unit as well as the attorney. The previous coordinating authority of the Attorney was transferred to the Corruption Eradication Commission, because it became the three institutions authorized to carry out investigations, namely Police, Attorney and Corruption Eradication Commission. Thus, according to the conception of legal substance of the three corruptions investigating institutions has the following authorities:

a. Police Corruption Unit investigators is solely authorized to carry out investigations;

b. The attorney investigator, in addition authorized to conduct an investigation, also acts as a public prosecutor;

c. The Corruption Eradication Commission investigator is entitled to conduct investigation, prosecution and also authorized to coordinate the investigation and prosecution carried out by investigator of Police Corruption Unit as well as attorney investigator.

In relation to the existence of Sub-Directorate III of Corruption under the Special Criminal Directorate of West Papua Police and Corruption Unit under the Kasat Reskrim in 9 Police Resort of West Papua Police is actually as result of Corruption Crime Investigation conducted by Corruption Unit Investigator of West Papua Police and several respondents as supervisory investigator, government agencies investigators and judiciary assume that Corruption Unit investigators has more role in carrying out enquiry and investigation duties. ${ }^{7}$

Follow-up enquiry and investigation of all police reports of alleged corruption in the last five years, according to the results of monitoring the proceedings, the suspects were proven legally and convincingly guilty of corruption, the judges' decision to convict the defendant is an evidence to the increasingly playing role of the enquiry and investigation of corruption that conducted by investigators/co-investigator of Corruption Unit of West Papua Police.

In relation to the presence of regulatory support in order to play a role in the enquiry and investigation of corruption by investigator/co-investigator of Corruption Unit of West Papua Police, generally respondents assess the norms and rules of law contained in legislation has a relatively large influence affecting the enquiry and investigation of corruption. The role of norms and legal are normative.

Legal uncertainty can lead to negative assumptions for law enforcement in Indonesia, it is necessary therefore for the government to respond to all the worst possibility of the existence of the three institutions of corruption investigation. At least the duties, functions and authority of Corruption Crime Investigation for Police investigators are exactly the same as the duties, functions and authority of the attorney's investigator, therefore one of them needs to be abolished so as to support the creation of legal certainty among the public.

The role of investigator in enquiry and investigation of Corruption Crime carried by investigator/coinvestigator of Corruption Unit of West Papua Police is inseparable from the ability of Human Resource of investigator/co-investigator in respecting, obeying and abiding the norms and unwritten legal norms.

These unwritten norms and rules of law are an integral part of the regulation, therefore the Police as the law enforcement apparatus are obliged to respect, obey and abide so that the enquiry and investigation of Corruption Crime becomes more role. Legal and social norms that are not written, its form of prohibition and

${ }^{7}$ Sukardi, Illegal Logging dalam Perspektif Politik Hukum Pidana: Kasus Papua, (Yogyakarta: Universitas Atma Jaya Press, 2005), page. 128 
appeal there is a punishment sanction and there is no punishment, but the violation against it will be labeled by society as an uncivilized (custom).

\section{Coordination and Cooperation for the Implementation of Corruption Investigation}

In essence, coordination and cooperation as important indicator for Corruption Unit Investigators in West Papua Police, to further enhance the role of its investigation of various forms of corruption that has damaged States' finances. Such investigation coordination should be intern of Poly particularly among the investigators themselves or in coordination with the units and working units which are in charge and the policy of investigation of the corruption.

In addition to the relationship of cooperation and coordination of the corruption investigation internally within the Police itself, then West Papua Police investigators always nurture and establish cooperation and coordination with outside parties, especially with the Corruption Eradication Commission ${ }^{8}$ and the public prosecutor. The result of this cooperation and coordination makes the investigation of corruption can be more important. The role of corruption investigation through the coordination is one of the sub-variables of the respondents' objector objectively to evaluate the support of the sub-variables of coordination quite positively, because generally the respondent assumes that the implementation of coordination played by the investigator of Corruption Unit of West Papua Police has contributed for support so that the implementation of investigation can achieve the goals and objectives. Based on interviews from respondents explains that coordination and cooperation between Corruption investigators and public prosecutors of West Papua Police experienced a constraint in the form of SPDP submission and submit the case files and extension of the handling of suspects who had been investigated by the West Papua Police investigation. The constraint in question are the absence of the High Court Office of West Papua, while the SPDP is submitted to the High Court of Papua and cannot be submitted to High Court of Manokwari, given that the stratum of West Papua Police is similar as the High Court Office of Papua, the distance of West Papua Police in Manokwari uses two path that is land and sea transportation, this became one of the respondents who argued that one of the constraints experienced corruption investigators of West Papua Police is the absence of the High Court in West Papua.

The implementation of good and regular coordination between the Corruption Unit Investigators of West Papua Police with the Police Work Unit or with their law enforcement personnel needs to be mobilized, and developed as it is through this coordination line so that the problems and constraint encountered during the corruption investigation can be solved. The Corruption Unit Investigator of West Papua Police in establishing cooperation with various parties still holds the principle of prudence and confidentiality, for the dignity and good name of a person or for the success of the investigation itself. The importance of maintaining confidentiality in carrying out his/her profession is consistent with existence. Investigators as members of the Police who are obliged to provide guidance to everyone including to someone suspected of involvement in the case of corruption (Article 13 paragraph (2) letter c of Act No.2 of 2002).

The obligation to keep and keep confidential is suitable to the provisions of the law in Article 6 paragraph (1) of Act No. 2 of 2002 which prohibits members of the Police to divulge the secret of police operations. One of police operation is the deepening and plans for the development of corruption in the stage or process of investigation. The application and implementation of take and give system is accompanied by the principles of prudential and confidentiality as applied by investigator/co-investigator of Corruption Unit of West Papua Police, so that the result of investigation on corruption can be optimized. One of the most important aspects that need special attention from the Corruption Unit Investigator of West Papua Police is controlling. In this section there are two inter-related, i.e supervision applying to action and controlling oriented to coaching for improvement. ${ }^{9}$ Sub-variables of supervision should be realized in a continuous or routine process of activities as the object and target of supervision are very broad and multi-complex, so that an efficient and efficient supervisory system is more likely to be applied for the investigation of corruption can be more optimized.

Another case with control that oriented to the coaching for improvement, object and target control focused on the case file as results of investigators conducted by Corruption Unit Investigator of West Papua Police. The expected output of control is the perfection of investigation so that the prosecutor can easily prove the criminal against the suspect in corruption proceedings. Furthermore, it is necessary to further examine the condition of sub-variable controlling that are expected to have an effect on the improvement of the performance of investigator members of Corruption Unit of West Papua Police, because the sub-variable of control is oriented towards improvement and more to the coaching, so it is reasonable if most respondents want the control

${ }^{8}$ The Komisi Pemberantasan Korupsi (KPK) is the Indonesian Corruption Eradication Commission, which was formed after special consideration on the extraordinary nature of corruption in Indonesia, which has become systemic and widespread, and has violated the human rights of the Indonesian people. The KPK was formed under Act No. 30 of 2002 on the Corruption Eradication Commission.

${ }^{9}$ Hibnu Nugroho, 2008, Efektivitas Fungsi Koordinasi dan Supervisi dalam Penyidikan Tindak Pidana Korupsi oleh Komisi Pemberantasan Korupsi, (Paper).Purwokerto: Universitas Jenderal Soedirman, pages. 398-399 
to be done for the success of the investigation of corruption crime. Sub-variable of control become one object of respondents' research, generally respondents have the same view that there are internal and external controls. Internal controls are within the organization of the Police itself either through the unitary media of work units, rank or working relationships between Police and among members of Corruption Unit investigator. While, the external control is normative in the Corruption Eradication Commission, and operationally there is in the attorney as the prosecutor. The sub-variable of control is expected to provide maximum support for the results of corruption investigation.

\section{CONCLUSION}

In fact, the implementation of Police Investigation' authority in corruption investigation in the field of Government's Goods and Services Procurement in West Papua Provincial, there are 2 (two) elements between prosecutor and Police investigators which implies not optimal the principle of checks and balances between the prosecutor investigator and Sub-Directorate III of Tipikor Ditreskrimsus of West Papua Police. The coordination between the investigation of goods and services procurement in West Papua Province by the prosecutors and corruption eradication investigators of West Papua police has not yet had a clear and still static for handling the corruption crime between the prosecutors and West Papua Police investigators. For the implementation of investigation authority as conducted by Sub Directorate III of Tipikor Ditreskrimsus of West Papua Police have clear procedure and criteria in the form of Standard Operational Procedure (SOP) in order to avoid dualism of investigation process either conducted by prosecutor or by Sub-Directorate III of Tipikor Ditreskrimsus of West Papua Police. Therefore, with the procedures and criteria that become the authority of each investigator is very urgent in maintaining the principle of check and balance. The implementation of corruption investigation by West Papua Police investigator and prosecutor or High Court of Papua is supported by coordination and integration to be a responsive law enforcement for corruption.

\section{REFERENCES}

[1] Komisi Pemberantasan Korupsi, Pedoman Pengendalian Gratifikasi, (Jakarta: KPK, 2015), page. 9.

[2] Roy, Subir Kumar. (2016). "Consumer Justice: A Symbol of Economic Prosperity and Social Progressiveness." Hasanuddin Law Review,2(2): 170-181. DOI: http://dx.doi.org/10.20956/ halrev.v1n2.302

[3] Ermansyah Djaja, Memberantas Korupsi Bersama KPK, Komisi Pemberantasan Korupsi, (Jakarta:Sinar Grafika, 2009), page. 28.

[4] Indriyanto Seno Adji, Arah Sistem Peradilan Pidana, (Jakarta: Prof. Oemar Seno Adji, S.H \& Co. Law firm, 2001), page. 46

[5] Sukardi, Illegal Logging dalam Perspektif Politik Hukum Pidana: Kasus Papua, (Yogyakarta: Universitas Atma Jaya Press, 2005), page.128

[6] Hibnu Nugroho, 2008, Efektivitas Fungsi Koordinasi dan Supervisi dalam Penyidikan Tindak Pidana Korupsi oleh Komisi Pemberantasan Korupsi, (Paper). Purwokerto: Universitas Jenderal Soedirman, pages. 398-399 